\title{
Impacts of Blockades and Strikes in Dhaka: A Survey
}

\author{
Ashik Mostafa Alvi, Nazifa Tasneem, Md Anik Hasan, Sumaiya Binte Akther \\ Department of Electrical and Computer Engineering, North South University \\ Bangladesh
}

\begin{abstract}
The general road blockade was headline news all over the world but in Dhaka, the news coverage was more intense in the last few years. In order to maintain the continuity of the countries activity smoothly, harmony in relation between its people is necessary. Unfortunately, it does not always run as expected. As a result, in some cases, a community of people chooses to use the blockade which includes stoppage of work, sit-ins, in severe cases burning cars, damaging road-side shops and other destructive activities. By creating these blockades, people sometimes gain their ulterior result but they actually do more damages in the economic, social and many other sectors of the country. In such a situation, it becomes difficult for general people to do their normal activities. Moreover, there is the fear of getting hurt or worse death. In this work, the reactions on these very recent blockades of different background people of Dhaka Metropolitan Area; the obstacles occurred due to blockades and the total loss of different sectors are figured out. Therefore, blockade parties should be required to negotiate to reach an agreement beforehand to minimize the loss and hassle of the mass people.
\end{abstract}

\section{Introduction}

In the recent years, blockade has become a regular activity in the city. For any kind of reason, a community of people chooses to use blockade and creates an unnecessary hassle for the general people. Because of these blockades, many problems arise for different sectors of people. Transportation problems, economical issues, medical emergency issues and so on. Again, several areas of Dhaka Metropolitan City are indeed a lot more dangerous than other areas [1]. So, there is a high chance of people getting injured or harassed.

From the beginning of the year 2013, the people of Bangladesh have encountered many strikes, seen many injuries and fatalities. Those strikes were often called by the opposition parties and almost every citizen of this city have become used to it. In that situation, people were seen burning due to thrown of petrol bomb in the running bus, dying pregnant mother due to firing pistol and postponing many National Education Board exams. Strikes have pushed people towards the worst phase of their lives. Bangladesh Nationalist Party (BNP) and Jamat-EIslam have set a new record by calling continuous strikes in those years.

However, this is an extension of the previous work [19]. Data was collected for the research work from the mass people of Dhaka city. In the twenty first century, students maintain a significant digital engagement [4]. That is why, in the previous paper, the first target was the students to collect the data via online survey. It was mainly from the undergraduate students of North South University (NSU) as there was not enough time to collect data from students all over the city. Local shopkeepers of Bashundhara residential area and Norda were also interviewed for more data.

After 2016, strike activity is not that often like the blockades. It has become new problem for the city people. It may not be always that intense as strikes but still do same damage; also it gets worse sometimes. In this paper, it is figured out that how much loss is encountered because of blockades and which problems are faced the most due to obstacles and how they affect people.

\section{Topic and its explanation}

The research topic was "Impacts of Strikes" previously. Refusing to work or in other sense, stopping the whole country to do their regular productive works is called strike. So, every individual of that country gets affected by strikes. It creates problems for the economy. In the new version of the paper, focus was more on the impacts of blockades among the people of Dhaka Metropolitan City. All the blockades and strikes cause threats to business about their survival. In the year 2013-2015, Bangladesh was going through a phase when people were not sure about their life whether they could come back home safely. People were afraid to open their shops; students could not go to schools, colleges or universities and were uncertain whether their exams would continue or not. Blockades also hampered their daily activities in various ways. All these thoughts pushed us to choose this topic and we have collected enough information and evidences to prove our hypothesis. 


\section{Importance of the topic}

Due to blockades, people of all classes are affected negatively. In the previous research, only two classes of people were focused who were affected by strikes: Students and Shopkeepers. School going students face difficulties in their Board Exams like SSC and HSC and it also harms their next phase of education. University going students face lots of extra academic pressure. Many shops were seen burnt and broken. These shops are mostly the small business entities that provide a significant amount in the Gross Domestic Product (GDP) of the country. However, in the extended work, we have focused on the people of all classes in Dhaka City. So, this research topic is found more significant with the running situation of Bangladesh.

\section{Background}

Strikes have different categories like student strike, labor strike and political strike. The recent strikes in Bangladesh are because of political issues. Besides, people are getting dependent on technological world to make their life easier and entertained [7]. They also use the advantage of technologies to communicate easily with people for calling strikes. Whatever the reasons are- strikes do impact academically, financially and psychologically.

According to a World Bank estimate in 2001, economic losses on account of strikes during 19951999 period stood at USD 10 billion, the per strikes loss being US $\$ 50$ million. Though UNDP estimated the cost of strikes on a longer-term basis. However, their findings seem to be in line with the World Bank. According to the UNDP estimate, strikes on an average took away 4.5 per cent of GDP per annum during 1991-2000 periods. The UNDP also thought this figure to have exceeded 9 percent per annum on three occasions during last decade [8].

Political unrest has been a cause of concern for many countries around the world, irrespective of their political regime or stage of improvement [14]. It is known that many political movements were organized and contributed by the students for the liberation of this country. During the mid-century, the students of this country moved forward and raised their protest for establishing Bangla as their mother tongue. But after the liberation, the situation has changed. Now the students are affected by the political parties' movement which are not always for the favor of the country.

Besides, universities remained closed during strikes, blockades and session jam occurred. For that, it took more time for the students of public universities to complete their graduation. Again, few students and teachers were involved with politics and so, some innocent of them were not safe during strikes. A female school teacher was killed this morning when picketers hurled brickbats at a vehicle carrying her in the district town during the countrywide hartal enforced by BNP-led 20-party alliance [16]. Only the innocent general people were the main victims. Students who were in schools and colleges faced immense trouble in giving their HSC and SSC exams. In 2013, exams of 37 Secondary School Certificate (SSC) subjects and 41 Higher Secondary Certificate (HSC) subjects were to be deferred due to similar protests by BNP-Jammat alliance [17].

There are many private universities in Bangladesh which are free of politics. Before 2001, students of private universities did not face session jam for completing their graduation. But from 2001, the brutality of strikes, blockade and other movement called by the political parties had took a new look. Common people including businessmen, teachers, students and shopkeepers started losing their lives and properties. So, the students of private institutions got scared to come out from home. The authority then took make-up classes, cancelled vacations and had to take rude decisions to finish up the syllabus in time. Students from English medium schools have a worse experience to share. Due to general strikes, their examinations are being scheduled at unusual hours actually in the middle of the night [2]. After 2009, strikes and blockades were continuing for months and the authorities failed to cover up the loss. There were no other options left to fall in session jam and authorities started to take classes. This decision had brought many physical harms to the university going students. Many died, many got injured. The government introduced the new law following an unprecedented movement by students for safer roads, after two students were killed in individual road accidents in Dhaka [11].

Our GDP (Gross Domestic Product) not only depends on the local people who are living here but also on the people who work outside of this country but send his or her earnings to Bangladesh. Many well-known garments had to cut down people for their losses during strikes. People earned and saved low amount and gained low profits because of this. In a rough estimation, 15 days of shutdown had cost the economy that is equivalent to $\$ 3$ billion, which could be used for the construction of the Padma Bridge. The costs do not take into account the brutal killing of people and damage to property. Since December last year, the country has witnessed exactly 15 days of strikes - each day causing a loss of around \$200 million, by one estimate. The estimated annual average cost of strikes is between 3 percent and 4 percent of the country's $\$ 110$ billion gross domestic product (GDP), according to a study. [5].

Due to strikes, Bangladesh's native image to the world is decreasing day by day. Foreign investments have stopped coming which reduce the foreign earnings. 
The losses because of strikes and its impacts have raised to an extreme level. These strikes typically last a whole working day although the duration could either be shorter or longer [15]. There were continuous strikes and blockade for two-three months which had crossed the previous losses and effects. The prices of onions, potatoes and some vegetables edged up amid inadequate supply, according to Trading Corporation of Bangladesh [5]. In some cases, the strike callers were so brutal to disrupt the railway and roadway communication. This kind of brutal activity took away so many innocent lives. People felt unsecured outside home. This disruption in communication system affected the public movement and the transportation of daily goods. No movement of inter and intra-district buses had left thousands of passengers in distress across the country [12]. Regular commuters were suffering extremely for lack of transportation [18]. From the very root level, the farmers could not send vegetables, rice, fishes, fruits and other goods to the cities. They also deprived of selling their products at good price. Torikul Islam, a farmer in Jessore, said that he had stopped selling potatoes for a long time as middlemen were offering low prices, citing a lack of transport movement [5]. Big industries which are depended on raw materials have to suffer much.

2020 is an era where economy is the main strength of a country. By calling continuous blockades and strikes, it has dropped down the economy. Actually, it has a chain of effects. It has affected the farmers, street vendors, retail shops, hawkers who have claimed low sells. We got low prices for vegetables such as beans and gourds as the number of wholesalers were low in the market and the quality of vegetables also falls unless we harvest in time, said Mohammad Shahbuddin, a farmer who lives in Narsingdi [5]. We have found two major effects of strikes. Firstly, political instability or uncertainty created by the violence. Secondly, political brutality which affects the poor class.

\section{Research areas}

In the previous work, the targeted groups were large in number. A survey was made among NSU students about their thoughts and sufferings from strikes. On the other hand, three interviews of Bashundhara Residential Area's shopkeepers and Norda's vegetable sellers were taken. The questions of the survey were as follows:

- How the students treat strikes?

- What are the troubles that students face due to strikes?

- Are there any long-term effects on students because of strike?

- Do the strikes help the students to do well in their exams?
- How the local shopkeepers treat strikes?

- What are the troubles that the local shopkeepers face due to strikes?

- What are the financial effects because of a strike on the shopkeepers?

- Is there any profitable part of strikes for the shopkeepers?

However, this time a survey is conducted about the impacts of blockades which have encountered in recent years. The questions were about the troubles people faced due to blockades. The survey questions were as below:

- Among recent blockades, did you find any of those logical?

- Do you support the recent blockades?

- Shopping/Economical problems which were created by blockades.

- Academic complications occurred-

- Medical issues that you had seen or faced-

- What are the transportation problems did you face during blockades?

- Events you missed on blockades day-

\section{Hypothesis}

Strikes cause threats to everyone and put up a question on the security of their assets and life as well. Strike or blockade puts transportation at their highest stake. It hampers the traffic polices to play their sincere role and if the traffic system of a country is not well managed, then the valuable life of every citizen faces a very critical risk [13]. Whether it be people or 'goods', nothing can be safely transported during strikes. These circumstances lead to less or no work which creates severe problem for the daily-wage earners. Because of the cocktail bomb fear people cannot go out. The number of vehicles decrease in the strike days. We think the long-term effect for the students is the session jam problem as the institution cannot finish up the syllabus within time. Again, blockades make the life painful; as it hampers people socially, economically, academically and almost in all situations.

\section{Methodology}

For the primary research, a survey was conducted to represent the students of Dhaka (NSU students) and interviewed Bashundhara Residential Area and Norda market's people. Useful data were collected which helped to prove the hypothesis with reasoning.

For the secondary research, help was taken from the internet, newspapers and some online journals from the social sites.

Moreover, another survey is done about blockades in recent years which have impact among the students and the local people of Dhaka city. 


\section{Data presentation and analysis}

In this work, necessary data is presented in different parts. The first part describes the primary data analysis, where we collected the data from the online survey. The second one is a physical interview taken from the shopkeepers of Bashundhara R/A and Norda area. Finally, the last part shows the secondary data analysis.

\subsection{Primary data presentation and analysis}

The data of 161 students were collected in the first survey, in which $77.6 \%$ were male students and $22.4 \%$ were female students and $64 \%$ live outside of Bashundhara R/A and rest $36 \%$ live inside Bashundhara R/A.

In the first question, the NSU students were asked about their thinking about strikes, where 52.2\% students think that strikes are called for hampering citizens' daily life. That means most of the students has negative thought about strikes. They do not love to spend a whole day without doing anything and also, they do not love to hamper their daily life by strikes.

At NSU, most of the students do not love make-up classes which has reflected when they were asked about the academic effect of strikes. $60.9 \%$ students think that academic effect of strike is lots of make-up classes. Another $25.5 \%$ students think that strikes destroy educational flow which has an effect on finishing the syllabus of a course in time (see Figure 1 for demographic information).

What is the academic effect of strikes? (161 responses)
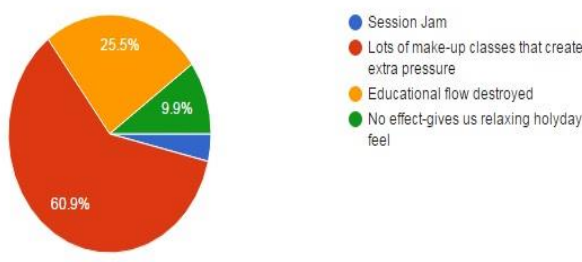

Figure 1. Demographic information about the survey question 2 [19]

When students were asked about the trouble they face during strikes, around $28.6 \%$ of them said that they face both transportation problem and security problem during strikes. It is very unethical to harass the students who are at their learning phase of life and one day they will be in charge of this country (see Table 1 for demographic information).

$42.9 \%$ students fear strikes for throwing petrol bomb on vehicles by the strike callers. It cannot be accepted that the policemen do bad behave with the general people especially with the students (see Table 2 for demographic information).
Table 1. Troubles people faced during strikes [19]

\begin{tabular}{|l|c|}
\hline \multicolumn{1}{|c|}{ Answer Options } & $\begin{array}{c}\text { Number of people } \\
\text { picked the option }\end{array}$ \\
\hline $\begin{array}{l}\text { Physical Harassment by } \\
\text { the strike caller }\end{array}$ & 5 \\
\hline Academic Loss & 12 \\
\hline $\begin{array}{l}\text { Never faced any trouble } \\
\text { for strike }\end{array}$ & 26 \\
\hline Less Transport & 29 \\
\hline Security Problem & 43 \\
\hline $\begin{array}{l}\text { Academic Loss and Less } \\
\text { Transport }\end{array}$ & 46 \\
\hline
\end{tabular}

Table 2. Fearing things during strike [19]

\begin{tabular}{|c|c|}
\hline Answer Options & $\begin{array}{c}\text { Percentage of } \\
\text { people chose the } \\
\text { option }\end{array}$ \\
\hline $\begin{array}{l}\text { 1. Throwing petrol } \\
\text { bomb on vehicle }\end{array}$ & $29.2 \%$ \\
\hline $\begin{array}{l}\text { 2. Indecent behavior } \\
\text { and harassment of } \\
\text { Policemen }\end{array}$ & $6.2 \%$ \\
\hline $\begin{array}{l}\text { 3. Less transport that } \\
\text { makes me worried } \\
\text { about going to } \\
\text { NSU and reaching } \\
\text { back home }\end{array}$ & $11.8 \%$ \\
\hline $\begin{array}{l}\text { 4. I don't fear } \\
\text { anything }\end{array}$ & $9.9 \%$ \\
\hline 5. 1,2 and 3 & $42.9 \%$ \\
\hline
\end{tabular}

After that, students were asked how they go to NSU if they have class on a strike day. $42.2 \%$ students used to depend on local bus to go to NSU. Some of them use their own private car or CNG or other transports. $18.6 \%$ students do not go to NSU during the strike because they do not feel safe in that situation to go outside (see Figure 2 for demographic information). 
Table 4. Class status on a strike day [19]
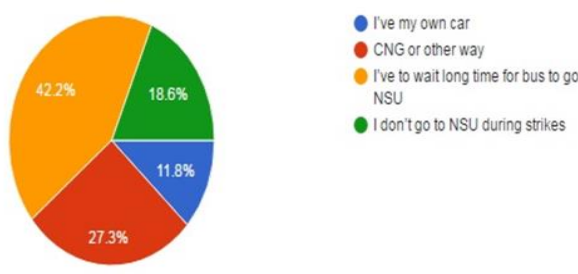

Idont too to NSU during strikes

Figure 2. Demographic information about the survey question 5 [19]

Again, the students were questioned about how they pass their time during strikes if NSU is closed. $44.7 \%$ students pass the day by sleeping and other $31.1 \%$ read novel or story book or watch serials. That means the students become academically detached (see Table 3 for demographic information).

Table 3. Activities during strikes [19]

\begin{tabular}{|l|c|}
\hline \multicolumn{1}{|c|}{ Answer Options } & $\begin{array}{c}\text { Percentage } \\
\text { of people } \\
\text { selected the } \\
\text { option }\end{array}$ \\
\hline $\begin{array}{l}\text { Reading Novel or Story } \\
\text { books, watching Serials or } \\
\text { Movie, playing indoor games }\end{array}$ & $31.1 \%$ \\
\hline $\begin{array}{l}\text { Completing my academic } \\
\text { tasks }\end{array}$ & $13 \%$ \\
\hline Sleeping all day long & $44.7 \%$ \\
\hline Others & $11.2 \%$ \\
\hline
\end{tabular}

When they were asked about their average study time during strikes (hrs.), in reply it is found that $43.5 \%$ students do not study during strikes which is very large in number. $52.8 \%$ students study only $3-8$ hours.

Moreover, the opinions of NSU students about their course status during strikes are- around 55.9\% teachers do not cancel their classes and it is difficult for the students to come NSU (see Table 4 for demographic information).

Besides, a target was to find out the effects of strikes on exams at individual level. $34.8 \%$ think that in this unofficial vacation students may get involved with unproductive activities, $23.6 \%$ students found no visible effects on exam, $23 \%$ think that students may get injured by the picketers and only $18.6 \%$ think that this unofficial vacation is helpful because they get extra time to make themselves prepared for the exams in a better way (see Table 5 for demographic information).

\begin{tabular}{|c|c|}
\hline Answer Options & $\begin{array}{c}\text { Percentage of } \\
\text { people picked } \\
\text { the option }\end{array}$ \\
\hline 1. $\quad \begin{array}{l}\text { Faculties cancel } \\
\text { classes }\end{array}$ & $11.2 \%$ \\
\hline 2. $\quad$ Remain same as usual & $55.9 \%$ \\
\hline 3. $\quad$ Exams are canceled & $9.3 \%$ \\
\hline $4 . \quad 1$ and 3 & $23.6 \%$ \\
\hline
\end{tabular}

Table 5. Effects of strikes on exams [19]

\begin{tabular}{|l|c|}
\hline Answer Options & $\begin{array}{c}\text { Percentage of people } \\
\text { chose the option }\end{array}$ \\
\hline $\begin{array}{l}\text { It helps to prepare } \\
\text { much well as there } \\
\text { are some extra time }\end{array}$ & $18.6 \%$ \\
\hline $\begin{array}{l}\text { Some students may } \\
\text { get injured because } \\
\text { of strike picketer }\end{array}$ & $23 \%$ \\
\hline $\begin{array}{l}\text { No visible effect } \\
\text { Because of extra time } \\
\text { some may get } \\
\text { involved in some } \\
\text { unproductive } \\
\text { activities }\end{array}$ & $23.6 \%$ \\
\hline
\end{tabular}

From the tenth question, it has been seen $57.8 \%$ students think that breaking the flow of education is the long-term effect of strikes and another $22.4 \%$ have a doubt that strikes may cause session jam. (see Figure 3 for demographic information).

What can be the possible long term effect of strike on students?

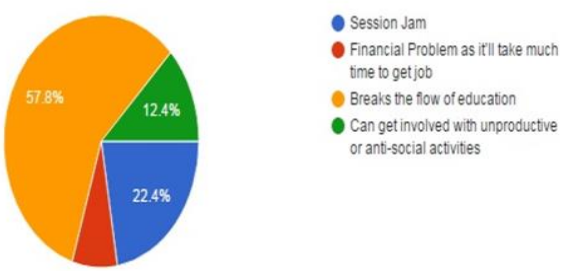

Figure 3. Demographic information about the survey question 10 [19]

Apart from these, it was the concern to find out if there is any positive effect of strikes. $38.8 \%$ students do not want to believe that there are any positive 
effects rather than pain and hassle. $23.6 \%$ students support strikes in one reason and that is no traffic jam in the road.

In the final question, it has been seen that around $80.1 \%$ students want NSU to remain close during strikes because of the safety issue and $9.9 \%$ do not want to remain close, means they want to continue the flow of education (see Figure 4 for demographic information).

Why you support NSU to remain closed during strikes? (161 responses)
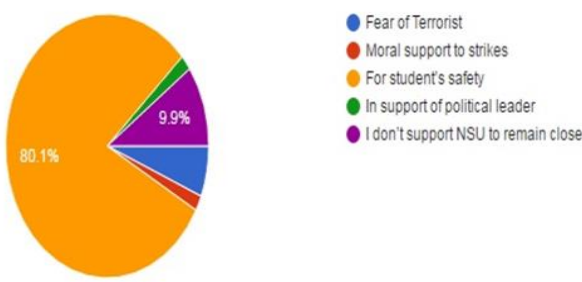

Figure 4. Demographic information about the survey question 12 [19]

All of these were from the previous work. After the acceptance of the paper, it has been extended as a journal. That is why, another survey was conducted among the people of Dhaka Metropolitan city, where the data of 203 people were collected.

In the first question, people were asked thatamong the recent blockades, if they think any of those logical or not. Then it is found that $69.5 \%$ people thought these blockades logical and $30.5 \%$ thought them illogical. That means, blockades occurred due to some logical reason according to the majority of the people.

The second question to the people was- whether they supported the recent blockades or not. Most of them gave their opinion that they supported blockades because of some reasons. Firstly, $38.9 \%$ people thought that- some blockades made them united on a national issue. Another $38.9 \%$ thought that- some of their valid demands were accepted due to the blockades. Besides, 33.5\% people supported blockades as they were unbiased non- political movement. However, $28.6 \%$ people were against the recent blockades.

Again, all of us have encountered some blockades in recent years which led us facing complications in our daily lifestyle. So the target was to get the opinion from people about their shopping or economic problems which were created by blockades. $69.5 \%$ people thought that price of daily necessary goods went up during blockades. Again, 34\% people said that some products got rotten due to late delivery. Moreover, products were not sufficient due to blockades. These facts ultimately led them to a great economic loss (see Table 6 for demographic information).
Furthermore, there were issues about the academic complications they faced during blockades.

Table 6. Shopping/economic problems created by blockades

\begin{tabular}{|l|c|}
\hline Answer Options & $\begin{array}{c}\text { Number of } \\
\text { people selected } \\
\text { the option }\end{array}$ \\
\hline $\begin{array}{l}\text { Products were not } \\
\text { sufficient }\end{array}$ & 49 \\
\hline $\begin{array}{l}\text { Price of daily necessary } \\
\text { goods went up }\end{array}$ & 141 \\
\hline $\begin{array}{l}\text { Number of sellers were } \\
\text { very few }\end{array}$ & 34 \\
\hline $\begin{array}{l}\text { Some of the shops were } \\
\text { closed }\end{array}$ & 53 \\
\hline $\begin{array}{l}\text { Some products got rotten } \\
\text { due to late delivery }\end{array}$ & 69 \\
\hline Others & 3 \\
\hline
\end{tabular}

Majority of the students, around $63.5 \%$ replied that their classes were canceled or there were low attendance in the class. Some of their exams were postponed or missed. Again, students do not like extra classes but $51.7 \%$ of them answered that makeup classes were scheduled because of blockades. They also complained that they did not get sufficient consultation hour. As a consequence of all these reasons, their semester got extended.

When people were questioned about the medical issues they had seen or faced, $54.2 \%$ people replied that they saw ambulances which were stuck on the roads during blockades. $48.3 \%$ also said that patients did not get their immediate treatment. Moreover, a large number of people thought that some people got injured because of the violation on the road which was very pathetic (see Figure 5 for demographic information).

Moreover, the transportation problems were a big fact which they faced during blockades. Around 65\% people responded that there were less number of vehicles, compared to the number of people waiting for the vehicles. Some of them also replied that there were no public vehicle. Besides, $45.8 \%$ people claimed that transportation fare raised up at that time. Overall, they were in trouble due to lack of sufficient vehicles. 


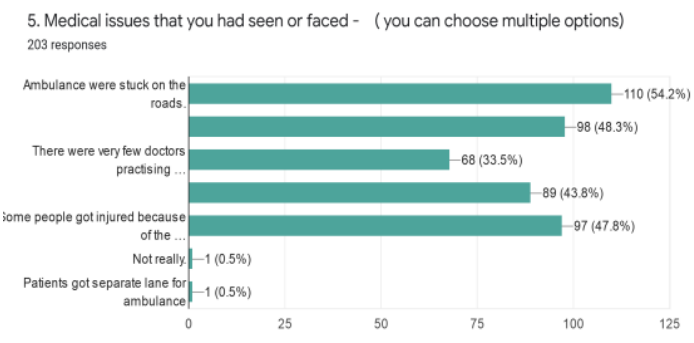

Figure 5. Demographic information about the new survey question 5

Lastly, people were questioned about the events they missed on blockades day. $46.3 \%$ people said that they missed their exam. Another $41.9 \%$ could not attend their social events. Many of them missed scheduled flight/bus/train/etc. So, they all were in trouble because of missing those events (see Figure 6 for demographic information).

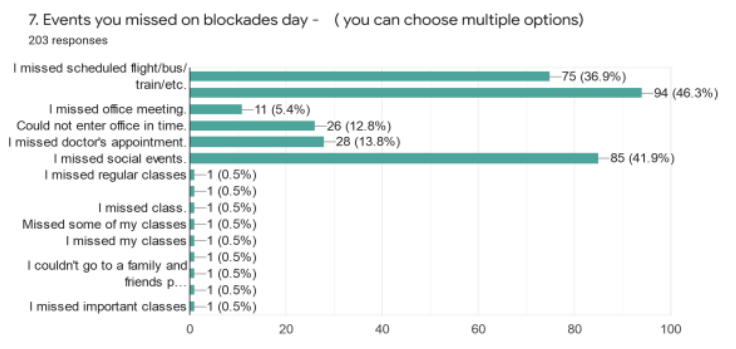

Figure 6. Demographic information about the new survey question 7

\subsection{Interview of Bashundhara $R / A$ and Norda area's shopkeepers}

The shopkeepers of these area claimed during daytime that they cannot sell their products. They cannot come to the shops and also customers cannot come. Because of the transportation problem, there is less supply of daily necessary goods.

All of the shopkeepers ensure that if there are ongoing continuous strikes, price of almost every goods increase. Daily necessary goods come outside of Dhaka city by truck. Fish sellers told that some of them increase the price on their own will to have some extra profit. Some sellers have to rent truck by their own to buy products from outside of Dhaka city. This extra transport cost is added with the price of goods.

Daily laborers like vegetable vendors', fish sellers' earnings depend on their daily sell. If there are continuous strikes they will get less supply and they will have very few profit from which they cannot lead their families well. Some sellers claimed they faced some picketers who did not allow them to bear their products and beat them. The sudden changes in selling quantity reduce the revenue and the rising prices along with rising costs reduce the profits.
A complain has raised by most of the sellers that continuous strikes decrease their daily income. Average income of these people is less than five thousand taka. But when it comes to continuous strikes, their average income decreases so much that it becomes very difficult for them to survive. In these circumstances, they become severely tensed for earning their livelihood.

\subsection{Secondary data presentation and analysis}

From the list of strikes [3] occurring in Bangladesh, AL, BNP and Jamaat / Shibir have given strikes in the history of their journey in politics. It has become a habitual fact for those political parties. The fact is, earlier strikes used to end in a day or two, but now strikes have become continuous and more severe. The oppositions declare strikes and blockades for any issue or action they do not like of the pro-government.

Last night miscreants threw a petrol bomb on a CNG-run auto rickshaw in Kazipara area, Mirpur, injuring three-member of a family. The injured were Shamsunnahar Begum, 45, hailed from Hatia of Noakhali, her son Tanjimul Haque, 22, student of Drama and Dramatics Department of Jahangirnagar University, and daughter Anika Aktar, a second-year student of HSC of Hatiya College [16].

The owners of the bus, truck and CNGs do not feel secured to send their vehicles on the street. For this reason, people get in trouble for going to their destination. At the same time, this is the cause of shortage of supply of products. Strikes have a great impact on Gross Domestic Product (GDP). Products are produced less and also the disasters done by the strikers threaten the GDP of the country because people cannot go to their workplaces.

\section{Discussion}

'Strikes are helpful for preparing well for the exams'- this hypothesis is not fully correct, rather NSU students think- because of this unofficial vacation, some students may get involved with unproductive activities. Except this one, rest of the hypothesis are almost accurate. Now the result of that survey is summarized here. Students treat strikes as an element which hampers their daily life. There is always some fear of security during those strikes. It is found that students hate attending make up classes. The trouble for the students is both academic and transportation related.

The university buses did not move from the campus to the city fearing the attack of patrol bomb by picketers. The students and teachers did not dare to board another vehicle to go the campus [9].

It is known that the brutality of strikes now reaches at its maximum level so that the strikers do not hesitate to throw petrol bomb to public transport and burn them. Eight people were burned in total, two of 
them were severely, in Comilla yesterday in a stupid petrol bomb attack on a running bus [6]. Journalists tried to capture the incident by using their Digital Image Capturing devices which have better support for noise reduction [10]. Another important finding is most of the students pass their unofficial vacation due to strikes by sleeping all day long if their university is closed. That means a working day is becoming unproductive for young generation. It is very challenging for the students to maintain their regular study during ongoing strikes. There is always insecurity on the public transport and on the road. So, the students have to take the risk to maintain academic activities. In the hypothesis, it is told that strikes give extra time to prepare more well for the exams but most of the students prove the thinking wrong. They think this extra time may be dangerous for them and some students may get involved to unproductive things. If the students are not busy with their studies, they may lose their interest. The target was to find out if there is any positive impact or result of strikes exists but most of the students do not think so. They think strikes only bring pain and hassle. Finally, the students' opinion were taken why they think their university should remain close during strikes. Many of them emphasize on the safety issue.

While interviews were taken near Bashundhara $\mathrm{R} / \mathrm{A}$, mixed opinions were found regarding strikes but most of them agreed that, they find difficulties to sell or buy products. Now it is confirmed that strikes increase the price of goods. Maximum time, prices are increased by the whole seller as there is less supply. Some shopkeepers said they increased the price to have little more profit than regular days. Majority of the shopkeepers fall in financial crisis for which their life becomes more complicated and hard to lead their families.

When the new survey was conducted about blockades, it was found that most of the people supported blockades for some reasons. Though they also agreed that they faced various kinds of problems. When they were questioned about shopping or economic problems, they gave various opinions as price of daily necessaries went up and so on. Some of the shops were closed and so on. Students also faced academic complications during blockades. Moreover, huge number of people had seen or faced medical issues. Patients suffered a lot due to road block. There were not enough doctors also.

Furthermore, transportation problem was a common issue during blockades. Lack of public vehicles, insufficient private vehicles, raising up of fare - were the major issues they faced. Besides, many people also missed some of their social events.

However, at the beginning of this research, there were many plans to execute but due to lack of time and bad weather, the expectation was not fulfilled properly. The plan was to include some other university, school and college students. For the interview, many places of Dhaka city were in the targeted list where always strikes are heavily hold. Moreover, it was a rainy season and so it was very difficult to move around Dhaka city and take interview or survey. Again, when the paper was accepted as an extended version of a journal, another survey was conducted about blockade issues. For doing this, there was not sufficient time and the survey was limited within the people of Dhaka city. If there were more time, people outside of Dhaka could be included.

\section{Conclusion}

Blockades mostly attack two sensitive classes of people of the society. One is the future leader of the country. Another is the lower-class people who are mostly daily laborer and shopkeepers. No positive impacts of strikes were found to those classes of people. Entire education system breaks down because of these blockades. Apart from this, shopkeepers are sort of daily laborers and many of them live under the poverty line. So, it will be better for the country's economy if the politicians stop calling strikes and blockades. Political strikes which led to blockades have put the economy under a lot of confusion about the future of the citizens and the country itself. The shopkeepers and vegetable vendors claim that strikes block the highways connecting town for which goods cannot come inside Dhaka. These circumstances create an unwanted shortage of supply of 'goods' which in turn increases price. The economists suggest that such political disputes should not be stretched but the political parties should sit together and find solutions to the problems. All of the first world countries have omitted these types of movements for the sake of their country's favor. So, we think it is high time for the decision makers of the country to give it much priority so that economy can raise upward and the students can continue their activities without any obstacles.

\section{References}

[1] Paul, S., Alvi, A. M., Nirjhor, M. A., Rahman, S., Orcho, A. K., \& Rahman, R. M. (2017). "Analyzing Accident Prone Regions by Clustering", Proceedings of the $9^{\text {th }}$ Asian Conference on Intelligent Information and Database Systems, Kanazawa, Japan.

[2] Kabir, E. (2013). Hartal and their effect on education. Dhaka Tribune. Online available at: http://www.dhakatribune.com/op-ed/2013/may/27/hartalsand-their-effect-education, (Access Date: 20 November, 2019).

[3] List of hartal in Bangladesh. (2019). Online available at: https://en.wikipedia.org/wiki/List_of_hartal_in_Banglades h, (Access Date: 11 August, 2019). 
[4] Alvi, A. M., Shaon, M. F. I., Das, P. R., Mustafa, M., Bari, M. R. (2017). "Automated course management system", Proceedings of the 12th International Conference for Internet Technology and Secured Transactions (ICITST), Cambridge, United Kingdom.

[5] Parvez, S., Barua, D. (2013). Economy reels from hartals. The Daily Star. Online available at: https://www.thedailystar.net/news/economy-reels-fromhartals, (Access Date: 16 November, 2019).

[6] Correspondent, S. (2015) Petrol bomb on bus again. http://www.thedailystar.net/frontpage/petrol-bomb-busagain-91771, (Access Date: 20 November, 2019).

[7] Hasan, M. A., Tasneem, N., Akther, S. B., Das, K., Alvi, A. M. (2019). "An Analysis on Recent Mobile Application Trend in Bangladesh", Proceedings of the Workshops of the 33 rd International Conference on Advanced Information Networking and Applications (WAINA-2019), Matsue, Japan.

[8] Rashid, M. (2012) Political economy of hartal. The Financial Express. Online available at: http://print.thefinancialexpress-bd.com/old/more.php?news id $=128346 \&$ date $=2012-05-01$, (Access Date: 14 November, 2019).

[9] SUST sustains hartal-blockade injuries. Sylhet Mirror. Online available at: http://sylhetmirror.com/archives/5306, (Access Date: 5 August, 2019).

[10] Alvi, A. M., Basher, S. F., Himel, A. H., Sikder, T., Islam, M., \& Rahman, R. M. (2017). "An adaptive grayscale image de-noising technique by fuzzy inference system", Proceedings of 13th International Conference on Natural Computation, Fuzzy Systems and Knowledge Discovery (ICNC-FSKD), Guilin, China.

[11] Staff Correspondent (2019) bdnews24.com. Commuters suffer as transport strike over new law rages on. Online available at:https://bdnews24.com/bangladesh/ 2019/11/20/commuters-suffer-as-transport-strike-overnew-law-rages-on?fbclid=IwAR1MILfGvQ6CtHD 4ATOEJR8Cdtv8-DF2NYRdP4lm2fEn116XuSbPgEcf1Y, (Access Date: 20 January, 2020).

[12] Transport strike called off after three days of public suffering. (2019). Dhaka Tribune. Online available at: https://www.dhakatribune.com/bangladesh/2019/11/21/tra nsport-strike-called-off-2?fbclid=IwAR2QR-Fo0vL7X QnuVu2Nq2zJtMNcMtC3RvxImG88M-NbljDzupA8fg tEgpQ, (Access Date: 20 January, 2020).

[13] Paul, S., Alvi. A. M., Rahman, R. M., "An Analysis of the Most Accident Prone Regions within the Dhaka Metropolitan Region," International Journal of Advanced Intelligence Paradigms (IJAIP), to be published.

[14] Shonchoy, Abu, Kenmei. (2016). Economic Impact of Political Protests (Strikes) on Manufacturing Firms: Evidence from Bangladesh. Institute of Developing Economies-JETRO. Online available at: https://mpra.ub.uni-muenchen.de/74146/, (Access Date: 20 January, 2020).
[15] Iqbal, K., Ahsan, R., (2014) Political Strikes and its Impacts on Trade. International Growth Centre. Online available at: https://www.theigc.org/wp-content/uploads/ 2015/02/Ahsan-and-Iqbal-2014-Working-Paper.pdf,

(Access Date: 20 January, 2020).

[16] Hartal passes of with the little impact on normal life. (2014) Bangladesh Sangbad Sangstha. Online available at: http://bssnews.net/newsDetails.php?cat $=0 \& i d=458778 \$$ dat e=2014-12-29\&dateCurrent=2019-11-20, (Access Date: 20 November, 2019).

[17] Staff Correspondent (2015) bdnews24.com. Thursday's SSC and equivalent exams postponed due to BNPsponsored shutdowns. Online available at: https://bdnews24.com/bangladesh/2015/02/11/thursdaysssc-and-equivalent-exams-postponed-due-to-bnp-sponsored-shutdowns, (Access Date: 2 August, 2019).

[18] Report, S. O. (2019). Rickshaw-pullers block road protesting rickshaw ban. The Daily Star. Online available at: https://www.thedailystar.net/city/rickshaw-pullersblock-dhaka-roads-protesting-rickshaw-ban-1768417, (Access Date: 20 January, 2020).

[19] Alvi, A. M., Tasneem, N., Hasan, M. A., Akther, S. B. (2019). "A Study to Find the Impacts of Strikes on Students and Local Shopkeepers in Bangladesh" World Congress on Sustainable Technologies (WCST-2019), London, United Kingdom., to be published. 